\section{Nitrogen Availability in Fresh and Aged Douglas Fir Bark}

\author{
M. Gabriela Buamscha ${ }^{1,7}$, James E. Altland ${ }^{2,8,9}$, \\ Dan M. Sullivan ${ }^{3,6}$, Donald A. Horneck ${ }^{4,6}$, \\ and John P.G. McQueen ${ }^{5}$
}

AdDITIONAL INDEX WORDs. potting mix, container substrate, decomposition, nitrogen competition, fertilizer

Summary. The objective of this study was to determine if there are growth differences in geranium (Pelargonium $\times$ hortorum 'Maverick Red') produced in fresh or aged douglas fir (Psendotsuga menziesii) bark (DFB). A second objective was to document nitrogen $(\mathrm{N})$ immobilization and decomposition rates of fresh and aged DFB to better understand the cause of growth differences. A series of experiments to measure plant response, $\mathrm{N}$ draw-down index (NDI), and percentage of cumulative carbon (C) loss were conducted on fresh and aged DFB. Geranium plugs were transplanted to containers filled with fresh or aged DFB. Treatments were arranged in a $2 \times 3$ factorial with two DFB ages (fresh and aged) and three $\mathrm{N}$ fertilizer rates $\left(200,300\right.$, and $\left.400 \mathrm{mg} \cdot \mathrm{L}^{-1}\right)$. Plant growth was affected by DFB age in that geraniums were smaller when grown in fresh DFB. $\mathrm{N}$ draw-down analysis demonstrated that a large fraction of $\mathrm{N}$ in solution was immobilized in fresh and aged DFB. Carbon loss, measured as a gauge of bark decomposition, was not affected by $\mathrm{N}$ rate or bark type. Similarities in $\mathrm{C}$ loss between fresh and aged DFB agree with the similar $\mathrm{N}$ immobilization potential (NDI) in the two materials.

$\mathrm{C}$ ontainer nurseries in Oregon use fresh and aged douglas fir bark (DFB). Although there is no general agreement as to what constitutes fresh, aged, or composted bark, the terms are used frequently in the nursery industry. For clarity, we offer the following descriptions of the three aforementioned bark types. Fresh bark refers to material sold soon after debarking from a tree, grinding, and screening to an appropriate

Special thanks to the Oregon Association of Nurseries for funding this research, and to Gilda Medina, Walter Briones, Vyacheslav Dobryk, Peng Yong, and Magdalena Zazirska for their skillful technical assistance.

Mention of proprietary products or company is included for the reader's convenience and does not imply any endorsement or preferential treatment by USDA/ARS.

${ }^{1}$ Cooperative Forestry, USDA Forest Service, P.O Box 3623, Portland, OR 97208-3623

${ }^{2}$ Application Technology Research Unit, Ohio Agricultural Research and Development Center, 1680 Madison Ave., Wooster, OH 44691

${ }^{3}$ Crop and Soil Science Department, Oregon State University, 3017 ALS Building, Corvallis, OR 97331

${ }^{4}$ Crop and Soil Science Department, Oregon State University, P.O. Box 105, Hermiston, OR 97838

${ }^{5}$ Department of Horticulture, Oregon State University, 4017 ALS Building, Corvallis, OR 97331

${ }^{6}$ Associate Professor.

${ }^{7}$ Western Nursery Specialist.

${ }^{8}$ Research Horticulturist.

${ }^{9}$ Corresponding author. E-mail: James.Altland@ars. usda.gov. particle size. Aged bark refers to material that goes through the same preparation process, but then also sits in undisturbed piles several months before use. Although processes may differ throughout the country, aged bark piles are often very large (up to $10 \mathrm{~m}$ high), exposed to ambient climate, and receive no additional inputs such as fertilizer, irrigation, or aeration. Composted bark refers to materials that have been processed to an appropriate particle size, arranged in piles (often less than $2 \mathrm{~m}$ high) suitable for turning and aerating, and often amended with supplemental fertilizers to promote decomposition. Composted bark is rarely used in Oregon container nurseries due to the additional costs associated with its preparation.
Physical and chemical properties of DFB as they pertain to use in nursery container substrates have only recently been studied. It was documented that fresh and aged DFB had different chemical properties; aged having lower $\mathrm{pH}$ and higher levels of extractable phosphorous $(\mathrm{P})$, calcium $(\mathrm{Ca})$, magnesium $(\mathrm{Mg})$, boron $(\mathrm{B})$, and iron $(\mathrm{Fe})$ compared with fresh (Buamscha et al., 2007b). A concurrent study used annual vinca [Catharanthus roseus 'Peppermint Cooler'] to evaluate micronutrient availability in DFB and found that fresh and aged DFB provided sufficient micronutrients for vinca without supplemental micronutrient fertilizers (Buamscha et al., 2007a). However, vinca growing in aged bark had higher stem biomass and foliar nitrogen $(\mathrm{N})$ than those in fresh bark after 8 weeks; differences were attributed to $\mathrm{N}$ availability.

Comparisons of fresh and aged pine (Pinusspp.) bark on plant growth have been made with several crops. Japanese holly (Ilex crenata' Rotundifolia') had similar size and quality when grown under a standard fertilization program in fresh or aged pine bark and with or without preplant $\mathrm{N}$ (Pokorny, 1979). Cobb and Keever (1984) compared fresh and aged pine bark amended with $\mathrm{l} \mathrm{kg} \cdot \mathrm{m}^{-3} \mathrm{~N}$ using a controlled release $\mathrm{N}$ fertilizer and at four levels of supplemental $\mathrm{N}[0,100$, 200 , and $300 \mathrm{mg} \cdot \mathrm{L}^{-1}$ ammonium nitrate $\left(\mathrm{NH}_{4} \mathrm{NO}_{3}\right)$ ]; growth of dwarf japanese euonymus (Euonymus japonica 'Microphilla') and japanese holly (I. crenata 'Compacta') in fresh bark equaled or exceeded that in aged bark at all levels of supplemental N. Harrelson et al. (2004) compared fresh and aged pine bark and three rates of controlled release $\mathrm{N}$ fertilizer (11.2, 22.2 , or $33.3 \mathrm{~g} /$ pot $\mathrm{N}$ ); bearberry cotoneaster (Cotoneaster dammeri

\begin{tabular}{llll}
\hline $\begin{array}{l}\text { Units } \\
\text { To convert U.S. to SI, } \\
\text { multiply by }\end{array}$ & U.S unit & SI unit & $\begin{array}{l}\text { To convert SI to U.S., } \\
\text { multiply by }\end{array}$ \\
\hline 29.5735 & $\mathrm{fl} \mathrm{oz}$ & $\mathrm{mL}$ & 0.0338 \\
0.3048 & $\mathrm{ft}$ & $\mathrm{m}$ & 3.2808 \\
2.54 & inch $(\mathrm{es})$ & $\mathrm{cm}$ & 0.3937 \\
25.4 & inch $(\mathrm{es})$ & $\mathrm{mm}$ & 0.0394 \\
0.5933 & $\mathrm{lb} / \mathrm{yard}{ }^{3}$ & $\mathrm{~kg} \cdot \mathrm{m}^{-3}$ & 1.6856 \\
28.3495 & $\mathrm{oz}$ & $\mathrm{g}$ & 0.0353 \\
1 & $\mathrm{ppm}$ & $\mathrm{mg} \cdot \mathrm{L}^{-1}$ & 1 \\
0.9464 & $\mathrm{qt}$ & $\mathrm{L}$ & 1.0567 \\
$\left({ }^{\circ} \mathrm{F}-32\right) \div 1.8$ & ${ }^{\circ} \mathrm{F}$ & ${ }^{\circ} \mathrm{C}$ & $\left(1.8 \times{ }^{\circ} \mathrm{C}\right)+32$
\end{tabular}


'Skogholm') grown in aged pine bark were larger than cotoneaster grown in fresh pine bark.

There is no distinction in the fertility programs used for production in fresh or aged DFB. Most nursery producers base their fertility rates on instructions provided by the fertilizer manufacturer written on the fertilizer bag. These rate guidelines are based solely on container size and plant requirement for "low," "medium," or "high" fertility. Based on research with pine bark, and related research conducted thus far with DFB (Buamscha et al., 2007b), there is reason to believe that $\mathrm{N}$ availability in fresh and aged DFB differs. Therefore, the objective of this study was to determine if there are differences in plant growth in fresh and aged DFB, and then to document $\mathrm{N}$ immobilization and decomposition rates of fresh and aged DFB to determine if growth differences can be attributed to microbial $\mathrm{N}$ competition.

\section{Materials and methods}

General information. Fresh and aged DFB samples were collected in Feb. and June 2006 from a major Oregon bark supplier (Marr Bros., Monmouth, OR). Fresh bark samples were debarked from their trees within $48 \mathrm{~h}$ of collecting; aged bark was collected from piles that had been stored at the processing site for $\approx 7$ months. The exact duration of the aging process at the time of sampling could not be determined. Bark was ground with a hammermill and passed through a 0.88 -inch screen. A series of experiments to measure plant response, $\mathrm{N}$ draw-down index, and percentage of cumulative carbon loss were conducted in fresh and aged DFB. The chronological progression of experiments are detailed in Table 1 . Methods for measuring plant response, $\mathrm{N}$ immobilization potential (NDI), and C loss are described, not necessarily in chronological order.

Plant response. On 19 June 2006, uniform plugs of 'Maverick Red' geranium $\approx 7 \mathrm{~cm}$ tall were transplanted to \# 1 containers $(3 \mathrm{qt})$ filled with DFB. Treatments were arranged in a $2 \times 3$ factorial with two bark types and three $\mathrm{N}$ fertilizer rates. Two bark types were fresh and aged DFB. A preliminary study was conducted in 2005 using $\mathrm{N}$ rates of 100,200 , and $300 \mathrm{mg} \cdot \mathrm{L}^{-1}$. Based on results from that study (data not shown), rates of

Table 1. Sequence of bioassays, nitrogen draw-down index (NDI), and carbon loss ( $\mathrm{C}$ loss) experiments conducted to understand nitrogen $(\mathrm{N})$ dynamics in douglas fir bark (DFB).

\begin{tabular}{lll}
\hline Date & \multicolumn{1}{c}{ Event } & \multicolumn{1}{c}{ Actions } \\
\hline & \multicolumn{1}{c}{ Geranium study } & \\
19 June 2006 & Initiated & Transplanted into DFB \\
24 July 2006 & First harvest $(\text { 5 WAP })^{\mathrm{z}}$ & SDW, Foliar N, SME \\
28 Aug. 2006 & Second harvest (10 WAP) & SDW, Foliar N, SME \\
& \multicolumn{1}{c}{ NDI and C loss study } & \\
Feb. 2006 & NDI & 1- and 4-d incubation \\
Feb. 2006 & C loss & 7- and 14-d incubation \\
June 2006 & NDI & 1- and 4-d incubation \\
June 2006 & C loss & 7- and 14-d incubation \\
\hline
\end{tabular}

${ }^{2} \mathrm{WAP}=$ weeks after planting, $\mathrm{SDW}=$ shoot dry weight, $\mathrm{SME}=$ saturated media extraction procedure.

200,300 , and $400 \mathrm{mg} \cdot \mathrm{L}^{-1}$ were used in this study. Each unique treatment combination was replicated 12 times (single plant containers) in a completely randomized design. All treatments were amended with $6 \mathrm{lb} /$ yard $^{3}$ dolomitic limestone $[0 \mathrm{~N}-0 \mathrm{P}-0 \mathrm{~K}-$ $22.7 \mathrm{Ca}-11.8 \mathrm{Mg}, 113$ calcium carbonate equivalency (Chemical Lime Lhoist Group, Salinas, CA)] and 1.5 $\mathrm{lb} /$ yard $^{3}$ Micromax (The Scotts Co., Marysville, $\mathrm{OH}$ ). Containers were fertilized with $90 \mathrm{mg} \cdot \mathrm{L}^{-1} \mathrm{P}$ and 225 $\mathrm{mg} \cdot \mathrm{L}^{-1}$ potassium $(\mathrm{K})$ using a potassium phosphate $\left(\mathrm{K}_{2} \mathrm{HPO}_{4}\right)$ solution. Plants received $250 \mathrm{~mL}$ of NPK fertilizer solution three times per week. Fertilizer solutions were prepared with tap water $\left(\mathrm{pH} 7.0,87.3 \mathrm{mg} \cdot \mathrm{L}^{-1}\right.$ alkalinity, $0.2 \mathrm{dS} \cdot \mathrm{m}^{-1} \mathrm{EC}, 2.1 \mathrm{mg} \cdot \mathrm{L}^{-1}$ $\mathrm{K}$, and no detectable $\mathrm{N}$ or $\mathrm{P}$ ). After three fertilization events, $250 \mathrm{~mL}$ of tap water was applied to leach the container and reduce salt build-up. The experiment was conducted in a retractable roof greenhouse (Cravo Equipment, Brantford, ON, Canada) in Aurora, OR (lat. $45^{\circ} 14^{\prime} \mathrm{N}$, long. $\left.122^{\circ} 45^{\prime} \mathrm{W}\right)$. The greenhouse roof was opened throughout the day, but was closed at night, such that daytime temperatures were similar to ambient outside temperatures, and night temperatures were maintained at $\approx 20^{\circ} \mathrm{C}$. The following data were collected 5 and 10 weeks after potting (WAP). Six plants were measured for shoot dry weight (SDW) by drying in an oven at $60^{\circ} \mathrm{C}$ for $72 \mathrm{~h}$. Foliar samples were harvested (Mills and Jones, 1996) by first rinsing with deionized water then drying the same as SDW samples. Samples were ground in a Tecator Cyclotec mill (Tecator AB, Hogenas, Sweden) through a 0.5$\mathrm{mm}$ screen and were analyzed for $\mathrm{N}$ by combustion using a $1500 \mathrm{~N}$ analyzer (Carlo Erba, Milan, Italy). Media samples were analyzed for $\mathrm{pH}$ by inserting a $\mathrm{pH}$ probe directly into a saturated paste (Warncke, 1998). Samples were further analyzed for ammonium $\left(\mathrm{NH}_{4}-\mathrm{N}\right)$ and nitrate $\left(\mathrm{NO}_{3}-\mathrm{N}\right)$ using a modified saturated media extract (SME) method with distilled water (Warncke, 1998). The modification to the standard SME procedure involved equilibrating the sample in water for $24 \mathrm{~h}$ (Gavlak et al., 2003) instead of $\mathrm{l}$ h (Warncke, 1998). Solutions were extracted by vacuum through Whatman No. 1 filter paper (Whatman PLC, Kent, $\mathrm{UK})$ and were then analyzed for $\mathrm{NH}_{4}-\mathrm{N}$ and $\mathrm{NO}_{3}-\mathrm{N}$ using a Lachat Quick Chem 8000 (Lachat Instruments, Milwaukee).

Plant response data were subjected to analysis of variance as well as trend analysis using contrast statements (SAS version 8; SAS Institute, Cary, NC) to determine the relationship between $\mathrm{N}$ rate and plant response. $\mathrm{N}$ draw-down and C loss data were subjected to repeated measures analysis of variance. C loss data were also subjected to trend analysis using contrast statements to determine if $\mathrm{NH}_{4} \mathrm{NO}_{3}$ rate influenced $\mathrm{C}$ loss.

Nitrogen DRAW-DOWN. Fresh and aged DFB samples were analyzed for NDI (Handreck, 1992a). Samples were collected and analyzed immediately at two times in Feb. and June 2006. Nitrogen draw-down is a measure of $\mathrm{NO}_{3}^{-}$disappearance after adding a $75 \mathrm{mg} \cdot \mathrm{L}^{-1} \mathrm{~N}$ solution as potassium nitrate $\left(\mathrm{KNO}_{3}\right)$ and incubating for 1 and $4 \mathrm{~d}$ at $22^{\circ} \mathrm{C}$ (NDI- 1 and NDI-4, respectively) following Standards Australia (2003). This index is a dimensionless ratio between $\mathrm{NO}_{3}^{-}$ concentration after incubating $\mathrm{l}$ and $4 \mathrm{~d}\left(\mathrm{NDI}-\mathrm{l}=\left[\mathrm{NO}_{3}{ }^{-}\right]_{\mathrm{d}} \mathrm{l} /\left[\mathrm{NO}_{3}{ }^{-}\right]_{\mathrm{d} 0}\right.$ 
and NDI-4 $=\left[\mathrm{NO}_{3}{ }^{-}\right]_{\mathrm{d}} 4 /\left[\mathrm{NO}_{3}{ }^{-}\right]_{\mathrm{d} 0}$, respectively). Data were subjected to analysis of variance.

Carbon loss. Decomposition rate as the percentage of cumulative $\mathrm{C}$ loss was determined via incubation (Anderson, 1982) on DFB samples collected in Feb. and June 2006. The procedure included fresh and aged DFB incubated at four $\mathrm{N}$ rates $(0$, 75,200 , and $400 \mathrm{mg} \cdot \mathrm{L}^{-1}$ ) using $\mathrm{NH}_{4} \mathrm{NO}_{3} \cdot \mathrm{KNO}_{3}$ at $75 \mathrm{mg} \cdot \mathrm{L}^{-1}$ was also included so $\mathrm{C}$ loss results could be compared back to NDI results and to determine if microbial populations had a $\mathrm{N}$ form preference. The incubation experiment is described as follows. DFB samples were allowed to warm to room temperature $\left(22^{\circ} \mathrm{C}\right)$ for $1 \mathrm{~d}$. Bark samples were thoroughly mixed and split into 500-g subsamples. Each subsample was submerged for $\mathrm{l} \mathrm{h}$ in an $\mathrm{N}$ treatment. Ten grams of gravity-drained bark was placed in l-qt canning jars. Treatments were replicated twice. An open vial with $20 \mathrm{~mL}$ of $\mathrm{l} \mathrm{M}$ sodium hydroxide $(\mathrm{NaOH})$ was placed in each jar and served as a carbon dioxide $\left(\mathrm{CO}_{2}\right)$ trap $\left[\mathrm{CO}_{2(\text { gas })}+\mathrm{NaOH} \rightarrow \mathrm{HCO}_{3}^{-}\right]$. Four blank jars (no bark) with $\mathrm{CO}_{2}$ traps were included as a control. Sealed jars were incubated at $22{ }^{\circ} \mathrm{C}$ for 7 and $14 \mathrm{~d}$. Vials with fresh $\mathrm{NaOH}$ solution were replaced at each incubation interval. $\mathrm{CO}_{2}$ evolution at 7 and $14 \mathrm{~d}$ was determined by titration of the nonreacted $\mathrm{NaOH}$. First, bicarbonate $\left(\mathrm{HCO}_{3}^{-}\right)$present in the $\mathrm{NaOH}$ is removed from solution as barium carbonate $\left(\mathrm{BaCO}_{3}\right)$ precipitate using $\mathrm{I} \mathrm{M}$ barium chloride $\left(\mathrm{BaCl}_{2}\right)$. The remaining $\mathrm{NaOH}$ is titrated with $0.1 \mathrm{M}$ hydrochloric acid (HCL) using phenolphthalein as the indicator.

\section{Results and discussion}

Plant Response. Substrate $\mathrm{pH}$ was lower in aged compared with fresh DFB at 5 and 10 WAP (Table $2)$. Previous research with nonamended DFB documented a similar difference in $\mathrm{pH}$ with bark age (Buamscha et al., 2007a). Cobb and Keever (1984) found higher leachate $\mathrm{pH}$ in aged pine bark compared with fresh. Harrelson et al. (2004) reported no effect of pine bark age on substrate $\mathrm{pH}$. Substrate $\mathrm{pH}$ decreased linearly with increasing $\mathrm{N}$ rate. $\mathrm{NH}_{4}$ $\mathrm{N}$ levels were similar between fresh and aged DFB at 5 WAP, but greater in aged DFB by 10 WAP (Table 2). $\mathrm{NO}_{3}-\mathrm{N}$ levels were higher in aged DFB throughout the study. $\mathrm{NO}_{3}-\mathrm{N}$ levels increased linearly with increasing $\mathrm{N}$ rate regardless of bark type or date, although the rate of increase was greater in aged than fresh bark. Across

Table 2. Substrate $\mathrm{pH}$, ammonium $\left(\mathrm{NH}_{4}-\mathrm{N}\right)$, nitrate $\left(\mathrm{NO}_{3}-\mathrm{N}\right)$, geranium foliar nitrogen $(\mathrm{N})$, and geranium shoot dry weight (SDW) grown in substrates containing fresh or aged douglas fir bark ages and three $\mathrm{N}$ rates. Data were collected at 5 and 10 weeks after planting $($ WAP $)(n=6)$.

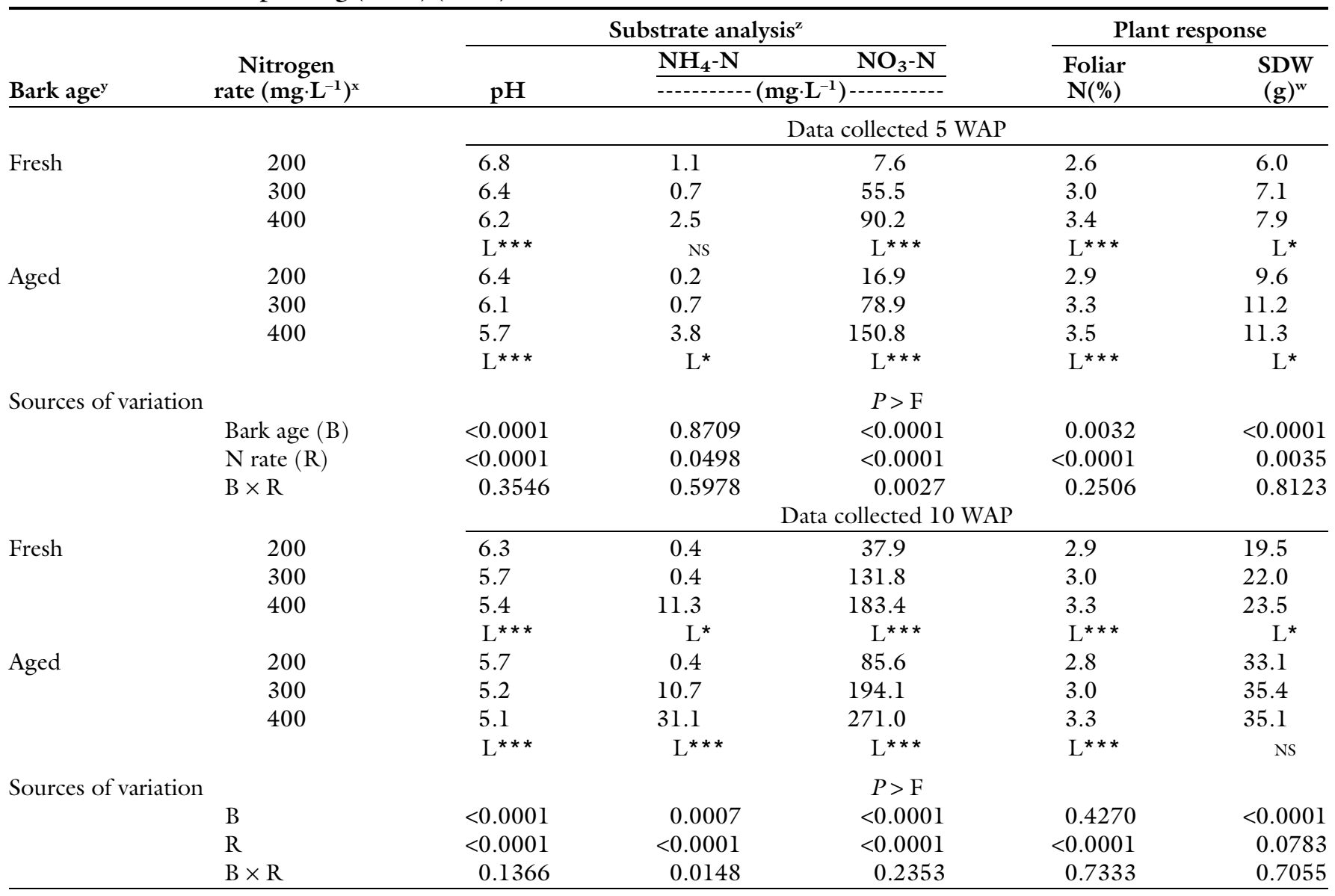

${ }^{\mathrm{z}}$ Media were analyzed with the saturated media extract procedure (Warncke, 1998).

${ }^{\mathrm{y}}$ Bark screened to 0.88 -inch $(2.235 \mathrm{~cm})$.

${ }^{x}$ Nitrogen source was ammonium nitrate applied three times per week; $1 \mathrm{mg} \cdot \mathrm{L}^{-1}=1 \mathrm{ppm}$.

${ }^{\mathrm{w}} 1 \mathrm{~g}=0.0353 \mathrm{oz}$.

$*, \star *, \star * *$ Represent a significant rate response when $P \leq 0.05,0.01$, and 0.001 , respectively.

$\mathrm{L}$ and $\mathrm{NS}$ represent linear and no significant rate response across $\mathrm{N}$ rate, respectively. 
all treatments, substrate $\mathrm{NO}_{3}-\mathrm{N}$ levels were higher than $\mathrm{NH}_{4}-\mathrm{N}$. This could be a result of preferential plant absorption of $\mathrm{NH}_{4}$ or nitrification. Either process releases hydrogen ions (Mengel and Kirkby, 2001), explaining the reduction in substrate $\mathrm{pH}$ with increasing $\mathrm{N}$ rate. Cobb and Keever (1984) also reported a reduction in $\mathrm{pH}$ with increased supplemental $\mathrm{N}\left(\mathrm{NH}_{4} \mathrm{NO}_{3}\right)$.

Across $\mathrm{N}$ rates, plants growing in fresh $\mathrm{DFB}$ had lower foliar $\mathrm{N}$ levels than in aged DFB at 5 WAP $(P=$ $0.0032)$; however, bark type had no influence on foliar $\mathrm{N}$ by $10 \mathrm{WAP}$ ( $P=$ 0.4270 ) (Table 2). Plants in fresh DFB grew less (smaller SDW) and had lower foliar $\mathrm{N}$ than those in aged bark at any given $\mathrm{N}$ rate. Pokorny (1979) did not find differences in fresh weight of holly grown in fresh or aged pine bark whether $1 \%$ of preplant $\mathrm{N}$ was added to compensate for potential $\mathrm{N}$ competition. This seems to imply no quantifiable $\mathrm{N}$ immobilization in pine bark. However, Pokorny seemed to contradict this finding by saying that preplant incorporation of $0.15 \mathrm{~kg} \cdot \mathrm{m}^{-3} \mathrm{~N}$ provides adequate $\mathrm{N}$ for microorganisms present in pine bark (suggesting microbial $\mathrm{N}$ competition). Cobb and Keever (1984) reported greater growth of dwarf japanese euonymus and japanese holly in fresh compared with aged pine bark. The authors proposed that the equal or higher plant growth in fresh compared with aged pine bark, even without supplemental liquid N, suggests a low $\mathrm{N}$ demand by microorganisms in both barks. However, their substrates were amended with a high $\mathrm{N}$ rate $\left(1 \mathrm{~kg} \cdot \mathrm{m}^{-3}\right)$ before planting. Similar to our findings, bearberry cotoneaster growth was greater in aged than in fresh pine bark (Harrelson et al., 2004). Harrelson concluded that plants in fresh pine bark did not require additional $\mathrm{N}$ as plants amended with $33.3 \mathrm{~g} /$ pot $\mathrm{N}$ were similar in size to plants amended with $22.2 \mathrm{~g} /$ pot N. If differences in $\mathrm{N}$ availability existed between the fresh and aged pine bark used by Cobb and Keever (1984) and Harrelson et al., (2004), they may have been masked by the high $\mathrm{N}$ rates used in both studies. Harrelson et al. (2004) attributed the higher plant growth in aged compared with fresh pine bark to differences in physical properties; substrate water holding capacity (WHC) for aged and fresh bark was $61 \%$ and $49 \%$, respectively. Physical properties of bark used specifically for our geranium study were not measured. However, physical properties of the same DFB source used to grow our geraniums were monitored for 1 year in a concurrent study (Buamscha et al., 2007 b). Substrate WHC averaged 32\% and $40 \%$ for fresh and aged DFB, respectively: Thus, higher $\mathrm{WHC}$ in aged DFB may have resulted in more available water and $\mathrm{N}$ to plants and overall increased geranium growth compared with the fresh material.

Nitrogen DRAW-DOWN. NDI analyses were conducted in an effort to explain differences in geranium growth in fresh and aged DFB. In Feb. 2006, a large fraction of $\mathrm{NO}_{3}{ }^{-}$ was removed from solution in both barks (Table 3). Similarly, June 2006 NDI results indicate high $\mathrm{N}$ immobilization potential in fresh and aged DFB, but no clear differences between the two bark types. After $4 \mathrm{~d}$ of incubation, NDI-4 for fresh and aged DFB was different $(P=0.078)$. N immobilization potential in DFB (NDI-4 = 0.160.29 ) is considered high compared with values reported for fresh and aged pine bark $(0.00$ and 0.09 , respectively) (Handreck, 1992b). Handreck (1992b) determined that media with NDI values near zero require 300 $\mathrm{mg} \cdot \mathrm{L}^{-1} \mathrm{~N}$ weekly, whereas media with NDI values near 0.5 consume $\mathrm{N}$ at a rate of about $40 \mathrm{mg} \cdot \mathrm{L}^{-1}$ per week. A high correlation between NDI value and growth was found in 'Grand Slam' cabbage (Brassica oleracea var. capitata) (Handreck, 1992b) and mexican mockorange (Philadelphus mexicanus)
(Handreck, 1993). In our study, the similar NDI values between fresh and aged DFB at the beginning of the geranium trial were not reflected in the measured disparate geranium growth at $10 \mathrm{WAP}$.

CARbon loss. Similar C loss results were measured in DFB collected in Feb. and June $2006(P=0.1344)$. As a consequence, only February data are presented and discussed (Table 4). $\mathrm{C}$ loss was unaffected by bark type or $\mathrm{N}$ rate. C loss did increase slightly from 7 to $14 \mathrm{~d}$, but was again similar across bark types and $\mathrm{N}$ treatments. Adding $\mathrm{N}$ from 0 to $400 \mathrm{mg} \cdot \mathrm{L}^{-1} \mathrm{did}$ not influence $\mathrm{C}$ evolution, indicating that biological activity was unaffected or limited by $\mathrm{N}$. There were no differences between $\mathrm{KNO}_{3}$ and $\mathrm{NH}_{4} \mathrm{NO}_{3}$ at $75 \mathrm{mg} \cdot \mathrm{L}^{-1}$, indicating no $\mathrm{N}$ form preference.

Gale et al. (2006) reported 0.3\% of $\mathrm{C}$ is lost per day from wellcomposted materials compared with higher than 1\% C lost per day from uncomposted materials. Decomposition rates for fresh and aged DFB were similar to those reported for well-composted materials by Gale et al. (2006). Up to $7 \mathrm{~d}$ of incubation, C loss was $0.27 \%$ per day across both DFB types and all $\mathrm{N}$ rates. From 7 to $14 \mathrm{~d}$, C loss dropped to just $0.1 \%$ per day, indicating that decomposition rates were slowing and suggesting that most microbial competition for $\mathrm{N}$, if any, would be early in the production cycle. Pokorny (1979) recommends preplant incorporation of $0.15 \mathrm{~kg} \cdot \mathrm{m}^{-3} \mathrm{~N}$ to satisfy microbial

Table 3. Nitrogen draw-down index $(\mathrm{NDI})^{\mathrm{z}}$ in douglas fir bark resulting from two bark ages and two collection dates.

\begin{tabular}{|c|c|c|c|c|c|}
\hline \multirow[b]{2}{*}{ Collection date } & \multirow[b]{2}{*}{ Bark age } & & \multicolumn{3}{|c|}{ NDI } \\
\hline & & & $\overline{\mathrm{NDI}^{-1} \mathbf{1}^{\mathrm{y}}}$ & & NDI-4 \\
\hline \multirow[t]{7}{*}{ Feb. 2006} & Fresh & & 0.59 & & 0.27 \\
\hline & Aged & & 0.45 & & 0.26 \\
\hline & & Univariate $P>\mathrm{F}$ & 0.592 & & 0.934 \\
\hline & & Multivariate $P>\mathrm{F}$ & & & \\
\hline & & Bark age $(\mathrm{B})$ & & 0.688 & \\
\hline & & Time $(\mathrm{T})$ & & 0.024 & \\
\hline & & $\mathrm{B} \times \mathrm{T}$ & & 0.423 & \\
\hline \multirow[t]{7}{*}{ June 2006} & Fresh & & 0.37 & & 0.16 \\
\hline & Aged & & 0.44 & & 0.29 \\
\hline & & Univariate $P>\mathrm{F}$ & 0.260 & & 0.078 \\
\hline & & Multivariate $P>\mathrm{F}$ & & & \\
\hline & & B & & 0.041 & \\
\hline & & $\mathrm{T}$ & & 0.005 & \\
\hline & & $\mathrm{B} \times \mathrm{T}$ & & 0.531 & \\
\hline
\end{tabular}

${ }^{2} \mathrm{NDI}=$ rate of disappearance of nitrate $\left(\mathrm{NO}_{3}\right)$ from an initial solution containing $75 \mathrm{mg} \cdot \mathrm{L}^{-1}(\mathrm{ppm})$ nitrogen (Handreck, 1992a).

${ }^{\mathrm{N} D I}-\mathrm{l}=\left[\mathrm{NO}_{3}\right]_{(\text {day } 1)} /\left[\mathrm{NO}_{3}\right]_{(\text {day } 0)}, \mathrm{NDI}-4=\left[\mathrm{NO}_{3}\right]_{(\text {day } 4)} /\left[\mathrm{NO}_{3}\right]_{(\text {day } 0)}$. 
Table 4. Percentage of cumulative carbon loss from fresh and aged douglas fir bark saturated with a solution of ammonium nitrate $\left(\mathrm{NH}_{4} \mathrm{NO}_{3}\right)$ at four nitrogen rates. Bark was collected Feb. 2006.

\begin{tabular}{|c|c|c|c|c|}
\hline \multirow[b]{2}{*}{ Bark age } & \multicolumn{2}{|c|}{ Nitrogen } & \multicolumn{2}{|c|}{ Incubation time $(\mathrm{d})$} \\
\hline & Source & Rate $\left(\mathrm{mg} \cdot \mathrm{L}^{-1}\right)^{\mathrm{z}}$ & 7 & 14 \\
\hline & & & \multicolumn{2}{|c|}{ Carbon loss (\%) } \\
\hline \multirow[t]{5}{*}{ Fresh } & 0 & 0 & 1.7 & 2.5 \\
\hline & $\mathrm{NH}_{4} \mathrm{NO}_{3}$ & 75 & 1.8 & 2.4 \\
\hline & $\mathrm{NH}_{4} \mathrm{NO}_{3}$ & 200 & 1.7 & 2.3 \\
\hline & $\mathrm{NH}_{4} \mathrm{NO}_{3}$ & 400 & 2.5 & 3.4 \\
\hline & & & $\mathrm{NS}^{\mathrm{y}}$ & NS \\
\hline \multirow[t]{5}{*}{ Aged } & 0 & 0 & 2.2 & 2.6 \\
\hline & $\mathrm{NH}_{4} \mathrm{NO}_{3}$ & 75 & 1.8 & 2.5 \\
\hline & $\mathrm{NH}_{4} \mathrm{NO}_{3}$ & 200 & 1.8 & 2.4 \\
\hline & $\mathrm{NH}_{4} \mathrm{NO}_{3}$ & 400 & 1.8 & 2.5 \\
\hline & & & NS & NS \\
\hline Sources of variation & & & \multicolumn{2}{|c|}{$P>\mathrm{F}$} \\
\hline Bark age $(\mathrm{B})$ & & & \multicolumn{2}{|c|}{0.231} \\
\hline Nitrogen rate $(\mathrm{R})$ & & & \multicolumn{2}{|c|}{0.223} \\
\hline $\mathrm{B} \times \mathrm{R}$ & & & \multicolumn{2}{|c|}{0.112} \\
\hline Incubation time $(\mathrm{T})$ & & & \multicolumn{2}{|c|}{0.001} \\
\hline $\mathrm{T} \times \mathrm{B}$ & & & \multicolumn{2}{|c|}{0.464} \\
\hline $\mathrm{T} \times \mathrm{R}$ & & & \multicolumn{2}{|c|}{0.102} \\
\hline $\mathrm{T} \times \mathrm{B} \times \mathrm{R}$ & & & \multicolumn{2}{|c|}{0.998} \\
\hline
\end{tabular}

${ }^{2} \mathrm{l} \mathrm{mg} \cdot \mathrm{L}^{-1}=1 \mathrm{ppm}$.

${ }^{\mathrm{N}} \mathrm{NS}$ represents nonsignificant response when $P>0.05$

needs. Our data do not validate the rate offered by Pokorny, but do suggest that if there is a microbial need for $\mathrm{N}$, it occurs soon after potting and thus preplant $\mathrm{N}$ applications are reasonable. Our data further suggest that the rate of preplant incorporated $\mathrm{N}$, although unknown, should be similar for both bark types.

Similar C loss between fresh and aged DFB agrees with the similarities in NDI values. We would expect that two materials with equal capacity to immobilize $\mathrm{N}$ would show similar decomposition rates (C loss). Furthermore, equal decomposition rates for fresh and aged DFB suggests that microbial immobilization of $\mathrm{N}$ may not be the primary mechanism of $\mathrm{N}$ disappearance.

Data herein demonstrates the effect of bark age and $\mathrm{N}$ fertilizer not only on plant response but also on $\mathrm{N}$ immobilization potential and media decomposition rate. A large fraction of $\mathrm{N}$ in solution was immobilized in fresh and aged DFB after $4 \mathrm{~d}$ of incubation (NDI-4). Carbon loss occurred at low predictable rates for a well-decomposed material, but there were no differences between fresh and aged DFB. Plant growth was affected by DFB age; geranium stem growth was always smaller in fresh bark. However, differential geranium growth between fresh and aged DFB cannot be explained by the observed similarities in $\mathrm{N}$ immobilization or decomposition rates between the two bark types. Other variables, such as differences in WHC between the two bark types, may have affected geranium growth. Many nursery growers incorporate a controlled release $\mathrm{N}$ fertilizer into the substrate before potting. Recently potted plants will not absorb $\mathrm{N}$ from the substrate until their root systems grow from their original root ball to explore the new substrate. Based on C loss data, N immobilization in both bark ages likely occurs very early in the production cycle when there is less demand for $\mathrm{N}$ by recently potted liners. Thus, $\mathrm{N}$ rates typically used by nursery growers are high enough to overcome $\mathrm{N}$ immobilization in either bark type.

\section{Literature cited}

Anderson, J.P.E. 1982. Soil respiration, p. 856-866. In: Methods of soil analysis, Part 2. Chemical and microbiological properties. Agron. Monogr. No. 9. 2nd ed. Amer. Soc. Agron. Soil Sci. Soc. Amer. Madison, WI.

Buamscha, M.G., J.E. Altland, D.M. Sullivan, and D.A. Horneck. 2007a. Micronutrient availability in fresh and aged douglas fir bark. HortScience 42:152-156.
Buamscha, M.G., J.E. Altland, D.M. Sullivan, D.A. Horneck, and J. Cassidy. 2007b. Chemical and physical properties of douglas fir bark relevant to the production of container plants. HortScience 42:1281-1286.

Cobb, G.S. and G.J. Keever. 1984. Effects of supplemental $\mathrm{N}$ on plant growth in fresh and aged pine bark. HortScience 19:127-129.

Gale, E.S., D.M. Sullivan, C.G. Cogger, A.I. Bary, D.D. Hemphill, and E.A. Myhre. 2006. Estimating plant-available nitrogen release from manures, composts, and specialty products. J. Environ. Qual. 35:2321-2332.

Gavlak, R., D. Horneck, R. Miller, and J. Kotuby-Amacher. 2003. Soil, plant, and water reference methods for the Western Region. 2nd ed. Western Coordinating Committee Nutrient Mgt. Publ. WCC103, Fort Collins, CO.

Handreck, K.A. 1992a. Rapid assessment of the rate of nitrogen immobilization in organic components of potting media: 1 . Method development. Commun. Soil Sci. Plant Anal. 23:201-215.

Handreck, K.A. 1992b. Rapid assessment of the rate of nitrogen immobilization in organic components of potting media: 2 . Nitrogen drawdown index and plant growth. Commun. Soil Sci. Plant Anal. 23:217-290

Handreck, K.A. 1993. Use of the nitrogen drawdown index to predict fertilizer nitrogen requirements in soilless potting media. Commun. Soil Sci. Plant Anal. 24:2137-2151.

Harrelson, T., S.L. Warren, and T. Bilderback. 2004. How do you manage aged versus fresh pine bark? Proc. Southern. Nursery Assn. Res. Conf.49:63-66.

Mengel, K. and E.A. Kirkby. 2001. Principles of plant nutrition. 5th ed. Kluwer Academic Publishers, Dordrecht, The Netherlands.

Mills, H.A. and J.B. Jones. 1996. Plant analysis handbook II. MicroMacro Publishing Athens, GA.

Pokorny, F.A. 1979. Pine bark container media: An overview. Proc. Intl. Plant Prop. Soc. 29:484-495.

Standards Australia. 2003. Method for the determination of nitrogen drawdown index, p. 24-27. In: Australian standard: Potting mixes. 4th ed. AS 3743 . Standards Australia Intl., Sydney.

Warncke, D. 1998. Recommended test procedure for greenhouse growth media, p. 34-37. In: W.C. Dahnke (ed.). Recommended chemical soil test procedures for the North Central Region. North Central Reg. Res. Publ. No. 221. Mississippi Agr. Expt. Sta. SB 1001. 